\title{
Ideological Dominance Structures in the Context of Organizational Culture
}

\author{
Dusan Schreiber \\ Federal University of Rio Grande do Sul, Rua Bolívia, 120, Pinheiros, 93042-160, São Leopoldo-RS, Brazil.
}

Accepted 19 September, 2013

\begin{abstract}
The legitimation of hierarchical power in the organizational environment, as a result of beliefs and traditions enshrined in the social structure since the establishment of the first organizational conformations, constitutes the foundation of the culture of domination in current organizations. In the name of organizational survival, the ends begin to justify the means, and the common good (whether real, imaginary, or artificial) rises above individual interests. Thus, managers, as the owners or legally designated and empowered agents of the means of production, legitimize their actions on the basis of the dominant ideology, which endorses reification of managerial actions and supports a predominance of rationality in decision making. The present article consists of a reflective analysis, based on an empirical case study, that seeks to evince the construction of managerial action by means of an ideological domination structure with the objective of introducing new organizational values of interest to the manager. The results evidenced "modus operandi" of the manager in relation to change in strategic focus of the organization, aiming to introduce new values in organizational culture, in order to provide the introduction of the innovative practices.
\end{abstract}

Key words: Conflict Resolution; Organizational Culture; Work Environment.

\section{INTRODUCTION}

Corporate organizations have their origin in the very first human societies; since time immemorial, artisans and craftsmen have organized into largely family-based structures, supported at most by a small group of apprentices. These crude, primitive structures underwent a process of evolution and selection leading up to the Industrial Revolution. Enterprises based on handiwork and crafting, characterized by a relative balance of power between the owners of the means of production and the workforce, were replaced by large industrial conglomerates (Maior, 1967; Moraes, 2000).

Thus, entrepreneurs, as capitalists (owners of the means of production), found themselves in the position of appropriating all factors involved in production so as to maximize economic return on investment. Their sole concern became competition with their peers-that is, other entrepreneurs, first those in their own countries and, as time went by, those overseas as well (Schumpeter, 1982; Marx, 1985). These changes in the manner in which resources are organized for product manufacturing had a significant impact on society and politics alike.

However, the establishment of the industrial conglomerate, which annihilated both the substance and spirit of craft production, enabled the emergence of a new social universe: the organizational environment. Although it is no more than a vignette of larger society, this environment exhibits characteristics that ultimately set it apart in a variety of aspects. Nevertheless, despite these differences, society and the company still share essential, structural traits, such as class division, ethnic culture, and 
national symbols (Barnard, 1979; Fayol, 1994; Bourdieu, 1998; Weber, 1999).

This differentiation is based on the routines, practices, myths, narratives, rules, and assumptions introduced to the organizational environment by its founder and reinforced (or not) by its management, which symbolizes power, legitimate or otherwise, within the organization (Weber, 1976). Over the years, the amalgam of sorts between the thought and action processes of individuals within the organization, who have a wide variety of interests, will permeate the social universe of the organization, either confirming or reshaping its set of rules, routines, and procedures. This is the process whereby a specific organizational culture is constructed.

This culture, however, may undergo a series of adjustments and changes, just as society may. These changes range from minor, trivial, even superficial adjustments to profound, radical change, which may lead to a complete reformulation of the organizational structure due to replacement of the individuals who ensured the maintenance of the cultural pillars of its social universe (Schein, 1988). In short, a series of factors may contribute to such reconfigurations of organizational structure, including changes in the context outside the organization and internal variables that have an impact on the organization's bottom line and corporate objectives (Pretorius and Steyn, 2005).

Innovation is one of the driving factors behind the need to rethink the forms of action of any firm on practically all aspects of its two core dimensions, technological and organizational (Tidd et al., 2005). It consisted of a shift of strategic focus away from simple price-based competition, toward competition based on superior quality and economies of scale, toward an emphasis on innovationbased competitiveness. Innovation is no longer an option; it is an essential condition for organizational survival. Thus, managers have the responsibility of finding ways of introducing innovation into the organizational environment (Landaeta, 2008).

In order to achieve this desired intent, the manager (entrepreneur or empowered agent) perceives a need to act not only on the surface of the organizational fabricthat is, on objective variables, behaviors, and attitudesbut also on subjective interpretations of reality (Weick, 1995). In this sense, there is evidence of growing use of an ever-broader range of means to achieve such action, with the aim of constructing and reconstructing organizational reality, with the endorsement and justifications of tradition and custom, constructed over the history of the firm, and legitimized by the pretense of defending the common good.

This article presents the case study of a family-owned technology business headquartered in Southern Brazil. On the basis of a perceived need to achieve a new competitive edge by means of product and process innovation, the new chairman of the organization-the son of the organization's founder-carried out a variety of actions with the intent of reshaping the organizational reality. Toward this end, he acted on both objective and subjective dimensions within the firm and employed all available means to introduce the practices he felt would be most adequate to ensure a strategic repositioning of the organization (Beer, 2010). Effective positioning was only attained after the incorporation of these practices into the organizational culture. However, to achieve this objective, the new chairman felt it would be essential to break free of the structures that supported the prior organizational structure, which had been constructed and were maintained by top- and mid-level professionals, who were thus laid off from the company.

This paper was developed with the aim of identify and characterize the form of management that influences the subjective dimension of the organizational environment. We begin by presenting some of the formative concepts of the theoretical framework through which the aforementioned empirical reality was interpreted and analyzed. We then introduce our research methodnarrative analysis, believed to be most in line with the objectives of this study-and, in the Results section, highlight the most relevant aspects of the evidence compiled. We conclude with some brief final remarks and our references.

The authors believe this brief foray into the theme will provide important insights that can encourage discussion of the practices adopted by organizations with the objective of acting on the subjective universe as a means of introducing new strategic values and vectors regarded as essential by top management.

1. Laying the foundations of conceptual structures of ideological dominance within the organizational environment

Historical records of ancient civilizations provide insight into the evolution of the organizational system, with an emphasis on the establishment of armies and religious organizations. However, there is also written evidence of corporate activity in the ancient world, which arose almost naturally when surplus production began to be bartered for items to which families and other groupsthe earliest communities and societies-had no access. To make transactions easier and standardize trade, the first common means of exchange were introduced, such as salt and spices; these later evolved to gold, coins, and negotiable instruments (Maior, 1967).

The processes of trade and industrial activity required consolidation, that is, organization, in order to enable better results, increased production volumes and sales, and entry into new markets. With the advent of the steam engine, which revolutionized the concept of industrialization and drove it towards mass production, with the construction of large factories and incorporation of massive contingents of former peasants into the labor force, this became an even more pressing need (Moraes, 2000). 
Several organizational concepts followed, and a variety of methods and techniques, geared mostly to manufacture and financial control, arose, as the objects of the earliest initiatives towards structural improvement of organizations as a means of achieving their prime objectives: profit and sustainability. In an attempt at mimicking the first major organizations-armies and the Church-their most representative symbolic elements, such as order, discipline, obedience, and control, in addition to mythical and cultural structures, were introduced to industrial organizations (Hoebel and Frost, 2001).

However, the first truly robust approach to the organizational management process, based on the tenets of the Cartesian-Newtonian paradigm and on the theoretical framework of Adam Smith (1981), was only conceived in the early 20th century by Frederick Taylor, in his Principles of Scientific Management (1995). In this publication, practically a handbook despite its primary focus on manufacturing, Taylor lays out the management process in outstanding detail, with particular emphasis on the division of labor, adequacy of workers to the tasks they are assigned, time study, and production methods. His core concerns were increasing productivity and achieving maximal efficiency in operational processes.

Almost contemporaneously, other lines of research began to stand out in the field of management studiesapproaches focused on organizing internal processes, particularly the work of French engineer Henri Fayol and German scholar Max Weber. In his most widely recognized work, Fayol (1994) stresses the importance of authority, responsibility, discipline, unity of command, direction, subordination of individual interest to common goals, stability, order, and centralization, among other principles. Weber (1976), complementarily, concerned himself with the relevance of topics such as hierarchy, predefinition of rules and procedures, formal and informal characteristics of behavior within organizations, hiring and promoting employees on the basis of technical competence and performance, the specialization of labor, and the specification of responsibilities. He also stressed the separation between the interests of the organization and those of its employees.

A similar line of research was followed by Chester Barnard (1979), who, in his book Functions of the Executive, sought to emphasize the importance of authority within the organizational structure, the need for establishing communication channels and reducing ambiguity and uncertainty in the organizational process, the importance of training personnel for their tasks, and the importance of absolute dedication to the organization. Though controversial, his opinions had a major impact on theoretical and empirical thought concerning the structuring of management processes within organizations.

In recent years, a series of studies aimed at conducting more in-depth research on the theme sought to portray the symbolic universe of organizations, identifying social and power relations and the mechanisms whereby subjectivity affects individual and collective performance (Bourdieu, 1998; Strati, 1998; Courpasson, 2000; Stokowski, 2002). This complex, multifaceted organizational environment has never again tolerated imprisonment in the cage of objective, simplistic concepts conceived by the classical and neoclassical schools, and has instead taken a leading role as the object of management research (Ismail and Abdmajid, 2007).

Organizations, whether for-profit or nonprofit, are points of reference and shapers of identity for most people living in our current society. Several sociologists have shown, theoretically and empirically, that work and employment are among the most important elements of personal development and satisfaction (Likert, 1975; Herzberg, 1997). Steady employment, an occupation, and a career build the structure required for the continuity of human life. These elements are among those most relevant for the development of individual knowledge and capacity, constitute a stable source of income and the foundation for providing for one's dependents, and are the core drivers of self-esteem and social status (Bernstein, 2005; Symon and Clegg, 2005).

Thus, the organization now represents the locus of professional and even personal accomplishment of its employees, who, by building meaning, eventually define their modus vivendi within organizational bounds (Weick, 1995; Stokowski, 2002). However, as in social life, the wealth of variables that compose organizational life transcends the conceptual scope. Nevertheless, one must at the very least define the basic elements that can guide the development of organizational analysis.

According to Costa (1987) and Bourdieu (2005), organizations should always be analyzed within their historical context, due to the interdependence between this context and society, of which organizations represent a "slice." Thus, the historical and social contexts are intrinsically intertwined, and their interaction creates a representation of a view of the world as perceived and interpreted. This idiosyncratic perception distinguishes one society from another, as it is the basis of its values, symbols, myths, and narratives; likewise, it distinguishes snapshots of society, including organizations (Simon, 1967; Vaughn, 1995; Strati, 1998; Symon and Clegg, 2005; Vergara, 2006).

Therefore, it is essential that the symbolic interpretation of the subjective dimension of organizations be addressed in order to understand the process whereby its variables influence and prompt managers to reshape reality as a means of achieving preconceived objectives.

\section{Subjective interpretation of social environments}

To Fischer (1996), Strati (1998), Daft and Weick (2005), and Bernstein (2005), social and organizational 
environments require interpretation. The actors that operate in the environment take on an active role of constructive events in order to give them meaning, on the basis of their behaviors and attitudes, taking stances, ignoring certain nuances and paying attention to others. Thus, interpretation is the process of translating organizational events and developing models for understanding, assigning significance, and establishing conceptual schemes.

Some years before, Weick (1995) had already identified and presented evidence to the effect that socially constructed realities exhibit a set of unique idiosyncratic characteristics. These include languages, symbols, meanings, data and information, the behavioral patterns of actors, and the manners in which social and organizational events, power relations, policies, history, metaphors, myths, issues, attributes, internal and external viewpoints, sensations, and games are interpreted.

Studies conducted by Vaughn (1995), on organizational symbology; Stevenson and Bartunek (1996), on power, interactionism, and organizational culture; and Stokowski (2002), on constructing senses within the organization, provided the understanding that social construction of the environment and of the meaning within it (on in which it is interpreted) enable redirection of the focus of the physical characteristics of the environment. Therefore, one may interpret that environments are always "in the process" of being created, always temporary and uncertain, always amenable to manipulation in order to satisfy individual or collective desires. Research also shows that value and sense are not inherent to the environment in time and space, but must be created and reproduced. The effort of creating the environment translates into the establishment of beliefs and values by the persons involved, expressed and encouraged by a promotion of the reality they desire (Beer, 2010).

According to Weick (1995), one of the components of interpretivism is sensemaking, which consists of four presuppositions: (i) activities and structures of organizations are determined in part by micro-momentary actions of their members; (ii) such actions are assumed to be based upon an information-processing sequence in which individuals attend to cues in the environment, interpret the meaning of such cues, and then externalize these interpretations via concrete activities; (iii) meaning is constructed when received cues are linked with welllearned cognitive structures; and (iv) individuals are able to verbalize the contents of their interpretations and the processes through which such interpretations were generated.

The values that influence perception of organizational reality are constructed by means of social interaction. Individuals create arguments and influence one another on the basis of their individual perceptions and representations of organizational values; hence the importance of the communication process as the main means for sharing ideas, images, and perceptions (Cohen and Levinthal, 1990). One may state that communication represents the process locus whereby individuals co-create, manage, and transform their own social realities. More than a mere co-orientation in the direction of a common set of meanings, individuals interpret the actions and discourse of others and coordinate their own actions according to the result of this interpretation (Symon and Clegg, 2005). This coordinated, interpretive process, which includes imagination, preconceptions, and interaction, produces the social reality of which the individual is a part (Buttle, 1994).

However, one must always bear in mind that every process comprises an overt structure and a hidden one, whether it is part of interaction, dialogue, planning, or negotiation (Gurteen, 1998). When one becomes aware of these structures of interaction and of the discourse they enable, language takes on a core role in shaping the desired reality, by means of relations with other individuals and with the world (Weick, 1995). Personal and organizational development requires new forms of relationships among individuals and between individuals and the environment (Chapman e Hyland, 2004). In order to achieve superior performance, individuals need new arguments on the world, environment, and life itself to structure their own identities and the organizational identity as well (Hansson, 2002).

These visible and invisible structures form an amalgam that underlies organizational culture, in a permanent state of flux, as the result of the influence of objective and subjective variables from the external and internal environment, ever pressuring, giving in, melding, adapting...

\section{The establishment of organizational culture}

Each culture has a unique way of seeing the world, that is, a perspective from which to interpret the universe of human experience. One's worldview usually consists of broader, more generic and, thus, more comprehensive concepts of how life works. This worldview partly aids in integration of perceptions and traits built on one's cultural background; it also provides support for interpretation of rules, customs, behaviors, and attitudes. Due to its degree of complexity, abstraction, subjectivity, scope, and number of facets, a worldview is rarely amenable to precise expression (Spradley, 1975; Souza, 1978; Schein, 1988; Geertz, 1989; Hoebel and Frost, 2001; Schneider and Barsoux, 2004).

Furthermore, the most relevant characteristic of the current historical context, both at the social and at the organizational level, is change (Lakomski, 2001; Miller, 2001; Ahn, Adamson e Dornbush, 2004). Perennial, institutional, constant, ever-accelerating, change is a representation of modernity itself, of economic, technologic, and even social development. Consequently, 
the word that best defines the present time is complexity.

To Perrow (1986) Motta and Caldas (1997), Morin and Clotet (2002), and Chapman and Hyland (2004), complexity is reflected in social situations and environments: people gravitate in a complex universe filled with sense and meaning. Since childhood, we seek to decode the symbols that represent the environment we live in, from the words of our parents and close relations to their expressions, postures, attitudes, and actionsalways assigning meaning (Johnson-Laird, 1988; Buttle, 1994; Blanchard et al., 1996; Ariely and Carmon, 2000; Haller and Hadler, 2006).

Senses, in turn, take on their own, non-universal meanings, which are conditioned to the languages that represent culture, that is, to a specific type of code. This code constitutes a reference framework that supports construction or reconstruction of the worldview. This framework is used in designating, classifying, linking, and ordering the universe. It also defines principles for classification whereby society can be segmented into distinct groups, and provides interpretive schemes that enable understanding of what is easy and what is difficult (Vaughn, 1995; Clegg, 1996; Chanlat and Bédard, 1996; Strati, 1998).

On the basis of this understanding, we may state that the concept of culture is essentially semiotic, based on the finding that we humans are somewhat held hostage by the meanings we ourselves have constructed. Therefore, it is an awareness of interpretive nature, not an experimental science in search of laws. Analysis thus consists of a choice between structures of signification, which can be defined as established codes, with the objective of determining the social foundation and its importance. Oftentimes, it entails facing a multitude of complex conceptual structures, many of which overlap or are linked to one another. Cultural analysis is inherently incomplete; even worse, the deeper the analysis, the more incomplete it is (Geertz, 1989; Hoebel and Frost, 2001).

However, according to Kluckhohn (1963), culture can still be defined as the overall way of life of a people, the social heritage acquired from one's group, a manner of perceiving, feeling, interpreting and believing, a sort of behavioral abstraction, a shared set of learning. It is also a set of standardized guidelines for frequently encountered problems: a form of learned behavior, a guiding mechanism for interpretation of attitudes and behaviors, a set of techniques for adjustment both to the external environment and in relation to other individuals.

Other authors, such as Souza (1978) and Schein (1988), also perceive culture as a set of control mechanisms-blueprints, recipes, rules, instructionstargeted at the behavioral domain. Many investigators, such as Simon (1967), Lukes (1993), Stevenson and Bartunek (1996), and Blanchard, et al. (1996), believe individuals may desire such control, even if subconsciously, and thus seek support from symbolic sources as a framework of reference for their actions (Vaughn, 1995; Strati, 1998).

Therefore, one may say that, if man were not directed by cultural standards-organized systems of significant symbols-behavior would be virtually ungovernable, chaotic, and based on meaningless actions. Research shows that the neocortex is incapable of governing behavior or experience in the absence of the guidance provided by significant symbol systems (Stern, 1971; Hall and Lindzey, 1973; Lundin, 1977). Culture, therefore, is an essential condition for its functioning, and the core foundation of its specificity.

In studying the phenomenon of culture, Souza (1978) and Schein (1988) state that culture can be divided into three elements, each of which encompasses a series of interdependent phenomena: (i) precepts regarded as a set of standards, values, regulations, management policies, traditions, management styles, and laws, as well as customs, rituals, patterns, and other tacitly followed informal patterns; (ii) technology, defined as a set of instruments, processes, layouts, distribution of tasks, division of labor, and organizational flow that support the technical, scientific, rational, and operational functions of the organization; (iii) character, as the set of active, affective expressions of individuals involved in the organization, their subjective manifestations, perceptions, feelings, and positive or negative reactions characteristic of group behavior.

To Kluckhohn (1963), Spradley (1975), Geertz (1989) and Hoebel and Frost (2001), ideas, values, actions, and even emotions are cultural products, that is, products manufactured on the basis of trends, capacities, and dispositions we are born with, but manufactured nonetheless. On the basis of this understanding, we may state that social relations, whether spontaneously constructed (friendship), determined by bonds of kinship (family), or occurring in formally established environments (organizations, neighborhoods, clubs, etc.) are also cultural products. In short, culture can be regarded as a process whereby a permanent construction and reconstruction of reality-of life itselfoccurs.

However, life is per se so complex and multifaceted that it is not easy to find a middle ground in the network of beliefs on which culture is built. Individuals may simultaneously perceive chaos between the parties involved and order between established judgments. Any attempts at definition and conceptualization fail if they attempt to account for all variables. Therefore, culture can also be interpreted as a series of structures of signification, through which men shape their experiences, with politics as the main arena in which these structures develop in public (Johnson-Laird, 1988; Weick, 1995; Vaughn, 1995; Strati, 1998).

Culture is viewed most effectively as a symbolic system, through the isolation of its elements, with the aim of characterizing the internal relations among these 
elements and thus specifying the system as a whole. Toward this end, it is important to focus on behavior, as it is through behavior-or, more properly, through the social actions originating in behavior-that cultural forms articulate. These forms are usually found in several types of artifacts and several states of awareness. In these cases, meaning emerges from the role played in the corresponding standard of living (Weick, 1995; Vaughn, 1995; Strati, 1998).

It bears stressing that cultural systems require a minimum level of coherence, otherwise they would not be systems at all. However, one must also bear in mind that highly coherent narratives are usually untrue, as proven by paranoid delusions and by the stories told by criminals (Plymire, 1993; Humphreys and Brown, 2002). Therefore, it is advisable that interpretive work not be based solely on the rigidity of internal structures and in the shelter of argumentative safety. A good interpretation of anythingof a person, organization, or story-must lead the interpreter to the core of what he or she wishes to analyze. Interpretation should, preferably, let the analyzer plot a curve of social discourse, providing a snapshot that is amenable to inspection. In this sense, cultural analysis is, or should be, a process of guessing meaning and assessing conjecture as a means of drawing explanatory conclusions (Geertz, 1989).

The importance of culture is also due to the role it plays in representing the link between what we have the potential to become and what each of us really becomes. To be "human" means to be unique. However, this individuality always takes shape under the guidance of cultural standards, historically established systems of signification that guide the shape, order, purpose, and direction of individual lives. Therefore, it is paramount to deal in details, go beyond the overt, beyond metaphysical types and hollow similarities, in order to achieve a correct understanding of contextually situated individual identity (Kluckhohn, 1963; Hoebel and Frost, 2001).

Recent anthropological studies have led to improvements in several concepts, such as those that concern the moral and aesthetic aspects of cultures and the value elements summarized by the term ethos, whereas cognitive and existential aspects were designated under the term worldview. The ethos would consist of the tone, character, and quality of life of a culture, in addition to its moral and aesthetic style, thus constituting its underlying stance toward itself and the world, which is reflected in life. Worldview, on the other hand, would be a plain depiction of things as they are in reality, nature, and society. This depiction probably includes the broadest ideas of order (Bernstein, 2005; Bourdieu, 2005).

Based on the evidence that confirms the structuring potential of the reality perceived and interpreted by employees, there is growing management interest in attempting to influence (or, in many cases, outright manipulate) the existing organizational culture (Bazerman
\& Moore, 2010). The following sections will present our empirical case study, starting with a description of our methods and characterization of the study company, followed by a reflective analysis of our findings, with the main goal of providing an understanding of the themes addressed using the preceding theoretical review as a foundation.

\section{CONTEXTUALIZATION AND CHARACTERIZATION OF METHODS}

Our chosen research method was the case study, which we believe is most closely aligned with the objective and research questions of this study. According to Tull and Hawkins (1976), the case study consists of an intensive analysis of a particular situation. Yin (2005) notes that the case study is best suited to analysis of contemporary events in situations where the events cannot be manipulated, but direct observation and systematic interviews are possible. Our study was carried out from an external vantage point, with no investigator involvement or manipulation of the events whatsoever, and the facts addressed by the study are contemporary. Among the many applications of the case study method as described by Yin (2005), the present study sought to describe a real-life context and conduct a descriptive assessment.

According to Bonoma (1985, p. 207), the case study is useful "when a phenomenon is broad and complex, where the existing body of knowledge is insufficient to permit the posing of causal questions, and when a phenomenon cannot be studied outside the context in which it naturally occurs." The goal of the case study method "is not quantification or even enumeration, but rather (1) description, (2) classification (typology development), (3) theory development, and (4) limited theory testing. In a word, the goal is understanding" Bonoma (1985, p. 206). The empirical portion of this study describes situations that actually took place and confronts them with the existing theory, constrained to the study organization.

This description is based on narrative analysis of unstructured interviews of nine employees working in the R\&D function of the study organization based on the following questions: (i) "How happened the process of forwarding the strategic focus of the organization, due to the new management?"; (ii) "What is the relevance of the innovation to the organization?"; (iii) "What is your contribution in the implementation process of innovation in the organization?". Interviews were transcribed and the resulting texts, naturally nonlinear and sometimes confusing due to the very nature of the interaction, were interpreted and rewritten as cohesive, naturally flowing first-person accounts. The reinterpreted narratives were then submitted to the interviewees for their appreciation and any adjustments or further contributions as necessary. Although this is not a recent research method, it is still regarded as innovative.

A narrative may be defined as organized discourse on a certain event, situation, subject, or theme. In a more detailed definition, it is the manner in which individuals relate their experiences; what they stress or omit, whether they portray themselves as protagonists or victims. It bears stressing that the relationship between the narrator and the listener means the narrative is not merely the telling of a story or event, but rather the construction of a personal identity (Riessman, 1993; Czarniawska, 2000).

One may state that written narrative-based research is basically the study of stories. Stories are omnipresent: they are found in descriptions of history, works of fiction, tales, autobiographies, and a variety of other literary genres. Stories originate in personal accounts of one's own history and the history of others, and are part and parcel of daily interactions. In addition to these spontaneous accounts, narrative research requires prompting for oral histories of specific themes, which will then be transcribed and 
analyzed. The study of narratives is considered a social research method (Polkinghorne, 2007).

Narratives are part of the cultural process whereby symbolic systems create and are created by means of discourse, and are also employed in different contexts as a means of communicating different points of view. Fragments of larger narratives and different versions of the same narrative are part of the daily discourse of all individuals, who are, after all, given being through a language based on concepts devised as a way of conveying meaning to the world they live in. These meanings are part of the network of conversation, and constitute a set of values, symbols, representations -in short, the very culture into which they integrate (Boje, 1995; Moen, 2006).

Text is interpreted and created with every word and phrase. Thus, contextualization of narratives is mandatory, as discourse is constructed from objective and subjective elements found in the environment of which it is a part and interprets them on the basis of its own assumptions, shaped by personal and professional experience. These assumptions become filters, standards of behavior, stances, and truths or untruths used by the individual to characterize certain situations, that is, to serve as parameters for classification of the nature of every occurrence (Riessman, 1993).

According to Czarniawska (2000), narrative analysis is an adequate method for revealing the processes employed by the narrator for interpretation, and is particularly indicated for assessment of individual interpretations of subjective themes, such as organizational culture. It is then up to the investigator to interpret the narrator's interpretations. However, it should be borne in mind that the investigator has no direct access to the experiences of others, and will thus always deal with distinct, ambiguous representations of experience, reported through speech, text, interaction, and, of course, acting.

Based on this finding, we believe that the symbolic-interpretive perspective, expressed by analysis of the discourse of the members of the study organization, is the most appropriate method for understanding these employees' perception of the social environment of the organization, in an attempt to recognize and identify the values, myths, symbols, and signs that contribute to construction of "organizational truths," of the "right" way of acting, the "right" way of thinking, and other aspects that have a direct impact on acceptance of the individual by the group, by the organization, and by groups within the organization. The symbolic approach is based on the concept of an organizational reality constructed by means of negotiation of symbolic universes and notions of mythic thought comprised in the positivist dilemma of true vs. false (Strati, 1998).

\section{Characterization of the study case}

The study organization, henceforth referred to as Gamma, is a chemicals company that has operated for 47 years in the paints and adhesives sector in Brazil and Latin America, with particular emphasis on the development of innovative, customized solutions for the shoemaking, furniture, construction, leather, and metalworking sectors. Gamma has over 500 employees distributed across production units in three Brazilian states and had earnings in excess of US $\$ 120$ million for the past fiscal year, obtained primarily from sales of a range of nearly 2500 products, including paints, varnishes, putty, textures, adhesives, solvents, and additives.

A family-owned business, Gamma was established when its founder was 23 years old. The young man had worked since the age of 13 as a house painter and decorator, letterer, and pinstriper, plying his trade primarily at local balls. He had always sought to carry out his duties with the utmost quality and with an edge over other tradesmen, particularly with regard to paint colors, which he formulated and mixed himself. His professional capacity and competence ensured his continued success, growing clientele, and, ultimately, financial independence. Fully accomplished in his trade as a freelancing craftsman, he had never even considered the possibility of starting his own company when a neighbor, the owner of a paint factory on the verge of closing, sought him out and offered him the business.

The young man bravely took up his neighbor's offer and placed his bets on the sector, following a path of constant innovation based on market trends and on his intuition. Over years and then decades, he transformed his small factory and highly artisanal manufacturing processes into a modern organization technologically aligned with current market leaders. Thirty-five years after its founding, the company established its first branch, in the Northeastern state of Ceará; one year later, it became one of the pioneers of $e$ commerce in the country; and two years after that, ISO 9001 certification was achieved.

In 2002, after 40 years of devotion to the company, the founder decided to relieve himself of his duties and focus on his social life, charitable activities, and leisure. He was succeeded as leader of the company by his two sons, who continued his trajectory of corporate success, as confirmed by the opening of a new branch in the state of Bahia, two years ago at the time of writing.

\section{ANALYSIS OF RESULTS}

During the research process, we interviewed nine employees working in research and development-the R\&D manager and eight product line coordinators. All interviewees shared one common trait: an educational background in engineering (chemical, production, mechanical). Employee age ranged between 25 and 40 years, which was surprising; as Gamma has been on the market for nearly 50 years and is widely recognized by employment stability and low turnover, we expected its workforce would be composed of older employees. The content of employee narratives basically provided evidence of the process described in the aforementioned paragraph, that is, a break in the management model due to two main vectors: (i) a change in market parameters, which mandated the establishment of a new competitive edge; and (ii) leadership succession, when the founder of the company ceded executive responsibility for all corporate operations to one of his sons.

The company's existing business model, as a provider of customized technical solutions for a pool of clients located mainly in the shoemaking industrial cluster of Southern Brazil through a corps of specialist technicians focused on specific clients and their specific issues, had exhausted itself. The company was forced to prospect alternative market niches which operated synergistically with its traditional market audience. The chosen alternative was to expand the scope of its range of paint products, originally devised for the shoe sector, to include the furniture, metal, and household segments. This entailed development of new competencies across all organizational areas, from procurement to sales, and investments on internal infrastructure (Bazerman and Moore, 2010).

However, as the new chairman soon realized after taking on his position, the main change requiring his direct involvement concerned bringing the employees' 
interpretation of reality in line with these new objectives (Cohen and Levinthal, 1990; Weick, 1995; Vaughn, 1995; Strati, 1998). According to the chairman, most employees were comfortable in their positions, providing no more than the minimum results consistent with the compensation provided and following organizational routines-that is, following the guidance that had been established by his father decades before, in flagrant contrast to the current corporate scenario. In the chairman's perception, unless the organization urgently implemented a new management model, it would be unable to survive in the market for more than 5 years.

Motivated by this perception and with the endorsement of a diagnosis developed in concert with specialist consultants and matured over a period of months by means of debates with top-level management and within the family, which held ownership of the company and thus remained one if its key stakeholders, the chairman decided a focus on innovation would be the organization's new competitive edge (Weick, 1995; Ismail and Abdmajid, 2007). Combined with a strategic reorientation for entry into new market niches, this focus on innovation became the main driving force of his tenure as chairman. At this point, company shareholders gave him carte blanche to implement any measures deemed necessary.

The first stage of the change process was confined to direct action on objective variables, which comprised allocation of resources for prospection of the company's new market niche, training of end-area professionals (such as R\&D, manufacturing, tech support, and sales personnel), and issuing instructions and setting goals and objectives. This was the easiest stage of the process, but also the least effective. An assessment showed that personnel, including senior managers and directors who had devoted decades of work to the organization and were respected by all lower-level employees, continued to dedicate themselves to traditional processes, in something of an attempt to "wait out the fad" until everything went back to normal (Stevenson and Bartunek, 1996; Stokowski, 2002; Beer, 2010).

The chairman soon understood he would have to devise an approach that would enable a complete break from existing values, the sense of which was based on stability, continuity, the absence of risk-in short, a complete break from the current perceived reality, which was reinforced by cultural symbols and an organizational discourse not in line with the new innovation-based focus he wished to implement (Weick, 1995; Strati, 1998; Symon and Clegg, 2005; Vergara, 2006). He thus realized there was a need to act on the subjective dimension that underlay the construction of the pillars that supported the existing organizational structure. Furthermore, he realized that, within the existing cultural context, most employees viewed this "new focus" as a breach of the contract they had signed upon entering the organization decades before. This contract did not provide for change, uncertainty, and doubt at a cognitive level; therefore, this first stage of the change process brought about fear, terror, and of course, resistance (Spradley, 1975; Souza, 1978; Schein, 1988; Geertz, 1989; Hoebel and Frost, 2001; Schneider and Barsoux, 2004).

However, resistance can only persist as long as it can find bastions of support. In the study organization, these were certain directors and managers who had long been key opinion leaders within the company and served as a reference for other employees. After consulting with company shareholders and, more importantly, with his father, the new chairman successfully demonstrated the severity of the company's predicament and the need for urgent action in order to reverse the indicators of competitive decline that confirmed his position, and obtained authorization to act by whatever means necessary to ensure the good of the company and preserve the interests of the majority (Landaeta, 2008; Beer, 2010).

With the support of specialized management consultants, a profile was drawn of the desired professionals that would shape the new organization and reinforce new values, concepts, and stances in line with its new strategic focus (Bernstein, 2005). A secret search for these new professionals began, and the second stage of the change process was implemented within a few months. All directors were replaced at once, as were $90 \%$ of managers-the latter gradually, over the course of two years. The company's new top-flight and midlevel managers, all younger professionals with prior experience in organizations that were more aggressive and more closely adapted to the new market reality, not only agreed with the focus on innovation but adopted a consistent discourse aligned with this focus and sought to actively disseminate new concepts among their teams (Beer, 2010; Bazerman \& Moore, 2010).

A new outlook, new ideas, and new concepts began to permeate the organizational environment and integrate with the organizational culture, initially melding with past values and concepts and eventually replacing them altogether. The "fad" became the rule, the required framework for all formal and informal interactions. Over a period of months, the stark initial division of subgroups into "the old" and "the new" faded; employees began to mingle on the basis of other interests, reshaping their perceived realities and giving rise to a new life cycle within the organization (Cohen and Levinthal, 1990; Symon and Clegg, 2005).

In order to consolidate these new cultural values, the third stage of the change process was implemented. Lectures were held with specific configurations tailored to each area, department, and subgroup. The company subscribed to several innovation-themed periodicals, copies of which were then strategically "left" in break rooms, cafeterias, etc. Email messages containing innovation-themed messages, including questions to 
which answers were expected, were periodically sent to employees (Johnson-Laird, 1988; Buttle, 1994; Blanchard et al. 1996; Ariely and Carmon, 2000; Haller and Hadler, 2006). Suggestion boxes for innovation-related comments were strategically placed throughout the company's facilities. Prize contests were held. Perceptions of innovation began to shift.

The content of these narratives shows that a consolidated process of product, process, operational, and supporting innovation practices is now firmly in place in the organization, endorsed by an innovation-geared organizational culture-the result of the successful efforts of the new management.

\section{CONCLUSION}

Competition has become increasingly fierce in certain segments, and organizations have been forced to adopt new operational profiles. In this scenario, establishing competitive edges and redefining strategic positioning have become very relevant tactics. Carrying out a process of reflection, assessing the firm's competitive conditions, and identifying a new strategic focus has become a priority for the majority of organizations in Brazil and abroad.

However, strategic reorientation often entails active changes in the organizational structure. These not only involve intervention on objective, overt process variables (routines and practices) with the intent of standardizing these variables and establishing new operational parameters, but also require action on the subjective dimensions of the organization. In essence, the process consists of introducing new organizational levels based on a new outlook for the company and its internal operations. Empirical evidence shows that managers have been employing all means at their disposal to achieve the objectives they deem desirable on the basis of their unique readings of the corporate context and their own personal experience. Backed by social beliefs and presuppositions that the ends justify the means as long as the former are in defense of the interests of the majority to the detriment of the minority, managers find themselves in a position of having both the power and authority to act as they deem fit in order to achieve predetermined objectives.

The present case study describes the strategic repositioning process of a family-owned chemical sector organization headquartered in the Porto Alegre metropolitan region in Southern Brazil. This repositioning began with corporate succession, in which control of the organization was transferred from its founder to his son, who carried out a process of diagnosis and realized the company was losing its competitive capacity and that urgent, effective action was required to reverse this situation and ensure survival.

In the first stage of intervention, the new chairman acted solely on objective factors, by means of instructions, rules, guidelines, and new goals and objectives. After some time, assessment showed that these efforts had not achieved the desired effect. In an attempt to pinpoint flaws in the process, the chairman noticed that personnel, including top-flight and midlevel management, had not in fact committed to the proposed new, innovation-based organizational focus, Career employees, some of whom had worked at the company for decades, believed the new chairman's ideas were no more than a "fad" and would be forgotten in time. They were wrong.

The new chairman, sure of his ideas and adamant to reposition the organization, secured the support of shareholders and, in a new intervention stage, decided to act on the subjective variables enshrined in the cultural fabric of the company. Upon determining that the organization's top and midlevel management simultaneously symbolized the prevailing organizational culture, served as focal points of resistance to change, and provided a frame of reference for other employees, the chairman decided to vacate all relevant positions and fill them with external candidates whose profiles were in line with the new objectives of the organization.

The new, younger professionals who came to hold the aforementioned positions became representations of the new values of the organization in the eyes of the other employees, breaking prior paradigms, changing processes and encouraging new attitudes, with a view to consolidation of the new management model. This action was complemented by planning and implementation of actions geared to fostering the topic of innovation, such as purchasing publications that were left in high-traffic areas, posters, brochures, emails, lectures, suggestion boxes, and in-house contests. After three years, the interviewees now believe the organizational culture is ties to a conceptual basis of innovation, in line with the new strategic focus of the firm.

The authors believe constant analysis of this article will enable reflection on the theme at hand and enable development of new lines of research.

\section{REFERENCES}

Ahn MJ, Adamson JSA, Dornbusch D (2004). From Leaders to Leadership: Managing Change. J. Leadersh. Organ. Stud. Spring. 10(4):112.

Ariely D, Carmon Z (2000). Gestalt characteristics of experience: the defining features of summarized events. J. Behav. Decis. Making. 13(2):191.

Barnard Cl (1979). As funções do executivo. São Paulo: Editora Atlas.

Bazerman MH, Moore D (2010). Processo Decisório. 7. ed. Rio de Janeiro: Elsevier.

Beer M (2010). Gerenciando mudança e transição. Rio de janeiro: Harvard Business Essentials.

Bernstein M (2005). Identity Politics. Ann. Rev. Sociol. 31:47.

Blanchard KH, Hersey P, Johnson D (1996). Management of Organizational Behavior: Utilizing Human Resources. Englewood Cliffs: Prentice Hall.

Boje DM (1995). Stories of the storytelling organization: A postmodern analysis of Disney as "Tamara-Land". Acad. Manage. J. 38(4): 9971035

Bonoma TV (1985). Case research in marketing: opportunities, problems 
and process. J. Marketing Res. 22(2):199-208.

Bourdieu P (2005). La práctica de la sociologia reflexiva. In: Bourdieu, Pierre; Wacquant, Loic. Una invitación a la sociologia reflexiva. México: Siglo Veintiuno Editores. pp.305-358

Bourdieu P (1998). O poder simbólico. Rio de Janeiro: Bertrand Brasil.

Buttle FA (1994). The co-ordinated management of meaning: A case exemplar of a new consumer research technology. Eur. J. Marketing. 28(8-9):76.

Chanlat A, Bédard R (1996). Palavras - a ferramenta do executivo. In: CHANLAT, Jean-François (Coord.). O indivíduo na organização: dimensões esquecidas. 3.ed. São Paulo: Atlas. P.2.

Chapman R, Yland P (2004). Complexity and learning behaviors in product innovation. Technovation 24(7):553-561.

CLEGG S (1996). Poder, linguagem e ação nas organizações. In: CHANLAT, Jean-François (Coord.). O indivíduo na organização: dimensões esquecidas. 3.ed. São Paulo: Atlas. P.2.

Cohen WM, Levinthal DA (1990). Absorptive capacity: a new perspective on learning and innovation. Admin. Sci. Quart. 35(1):128152.

Costa MCC (1987). Sociologia: introdução à ciência da sociedade. São Paulo: Moderna.

Courpasson D (2000). Managerial strategies of domination - power in soft bureaucracies. Organ. Stud. 21(1):141-161.

Czarniawska B (2001). Anthropology and Organizational Learning, cap. 5, p. 118-136. Do Handbook: DIERKES, Meinolf; ANTAL Ariane. B. CHILD, John; NONAKA, Ikujiro (Orgs.). Organizational Learning and Knowledge, New York: Oxford.

Daft R, Weick KE (2005). Por um modelo de organização concebido como sistema interpretativo. Revista de Administração de Empresas - RAE. 45:73-86.

FAYOL H (1994). Administração industrial e geral: previsão, organização, comando, coordenação, controle. São Paulo: Editora Atlas.

Fischer G-N. (1996) Espaço, identidade e organização. In: CHANLAT, Jean-François (Coord.). O indivíduo na organização: dimensões esquecidas. 3.ed. São Paulo: Atlas. P.2.

Geertz C (1989). A interpretação das culturas. Rio de Janeiro: LTC.,

Gurteen D (1998). Knowledge, creativity and innovation. J. Knowl. Manage. 2(1):5-13.

Hall CS, Lindzey G (1973). Teorias da personalidade. São Paulo: Editora Pedagógica e Universitária Ltda.

Haller M, Hadler M (2006). How social relations and structures can produce happiness and unhappiness: an international comparative analysis. Soc. Indic. Res. 75:169-216.

Hansson T (2002). Leadership by Activity Theory and Professional Development by Social Construction. Syst. Pract. Action Res. 15(5):411.

Herzberg F (1997). Mais uma vez: como motivar seus funcionários? In: VROOM, Victor $\mathrm{H}$. Gestão de pessoas, não de pessoal: os melhores métodos de motivação e avaliação de desempenho. São Paulo: Ed. Campus. pp.55-82

Hoebel EA, Frost EL (2001). Antropologia cultural e social. São Paulo: Cultrix.

Humphreys M, Brown A (2002). Narratives of organizational identity and identification: a case study of hegemony and resistance. Organ. Stud. 23(3):421-447.

Johnson-Laird PN (1988). How is meaning mentally represented? International Soc. Sci. J. 40(1):45-61.

Kluckhohn C (1963). Antropologia: Um espelho para o homem. 1. ed. Belo Horizonte: Itatiaia. P.301.

Lakomski G (2001). Organizational change, leadership and learning; culture as cognitive process. Int. J. Edu. Manage. Bradford. 15(2):68

Landaeta RE (2008). Evaluating Benefits and Challenges of Knowledge Transfer Across Projects. Eng. Manage. J. 20(1):29-38,

Likert R (1975). Organização humana. São Paulo: Atlas,. (Capítulo 3 Produtividade e relações de trabalho sob diferentes sistemas administrativos).

Lukes S (1993). Power: a radical view. New York. MacMillan.

Lundin RW (1977). Personalidade - uma análise do comportamento. São Paulo: Editora Pedagógica e Universitária Ltda.

Maior AS (1967). História Geral. São Paulo, Editora São Paulo. P.190.

Marx K (1985). O capital. São Paulo: Editora Abril.
Miller BP (2001). Leadership, Organizational Culture and Managing Change: A Case Study of North Carolina's Johnston Community College. Tese de Doutorado de North Carolina State University.

Moen T (2006). Reflections on the Narrative Research Approach. Int. J. Qual. Meth. 5:(4).

Moraes JGV (2000). Caminhos das Civilizações. São Paulo: Editora Saraiva.

Morin E, Clotet J (2002). As Duas globalizações: complexidade e comunicação : uma pedagogia do presente. 2. ed. Porto Alegre, RS: Sulina Universitária, EDIPUCRS.

Motta FC, Caldas M (1997). Cultura organizacional e cultura brasileira. São Paulo: Atlas.

Perrow C (1986). Complex organizations: a critical essay. New York: McGraw-Hill. Capítulo 2 - Managerial ideologies and the origins of the human relations movement. pp.49-78.

Plymire J (1993). The Depth Psychological Implications of Ogranizational Culture. Tese de Doutorado da Pacifica Graduate Institute.

Polkinghorne DE (2007). Validity issues in narrative research. Qual. Inq. 13(4):471-486.

Pretorius CJ, Steyn H (2005). Knowledge management in project environments. S. Afr. J. Bus. Manage. 36(3):41-50.

Riessman CK (1993). Narrative analysis. London: SAGE.

Schein EH (1988). Organization Culture and Leadership. San Francisco: Jossey Bass.

Schneider S, Barsoux J (2004). Culture and organization. In: Barlett, C. A.; Goshal, S.; Birkinshaw, J. Transnational Management: text, cases and readings in cross-border management. 4th ed. McGrawHill Irwin. New York.

Schumpeter JA (1982). Teoria do desenvolvimento econômico: uma investigação sobre lucros, capital, crédito, juro e o ciclo econômico. São Paulo: Abril Cultural.

Simon H (1967). Comportamento administrativo. Rio de Janeiro: Fundação Getúlio Vargas.

Smith A (1981). Inquérito sobre a natureza e a causa da riqueza das nações. Lisboa: Fundação Calouste Gulbenkian.

Souza ELP (1978). Clima e Cultura organizacional: como se manifestam e como se manejam. São Paulo: Edgard Blücher.

Spradley JP (1975). Anthropology: The cultural perspective. 1. ed. New York: John Wiley \& Sons.

Stern W (1971). Psicologia Geral. Lisboa: Fundação Calouste Gulbenkian.

Stevenson WB, Bartunek JM (1996). Power, Interaction, Position and the Generation of Cultural Agreement in Organizations. Human Rel. 49(1):75.

Stokowski PA (2002). Languages of place and discourses of power: Constructing new senses of place. J. Leisure Res. Fourth Quarter. 34(4):368.

Strati A (1998). Organizational symbolism as a social construction: A perspective from the Sociology of Knowledge. Human Rel. 51(11):1379

Symon G, Clegg C (2005). Constructing identity and participation during technological change. Human Rel. 58(9):1141.

Taylor FW (1995). Princípios de Administração Científica. 8ª ed. São Paulo: Atlas, Fundamentos da Administração Científica - pp.24-36; Princípios da Administração Científica - pp.37-55, 60-62, 67-74; 8595.

Tidd J, Bessant J, Pavitt K (2005). Managing innovation: integrating technological, market and organizational change. 3. ed. Chichester: John Wiley \& Sons, Ltd.

Tull DS, Hawkins DI (1976). Marketing Research, Meaning, Measurement and Method. Macmillan Publishing Co., Inc., London.

Vaughn MA (1995). Organization Symbols: An Analysis of their types and functions in a reborn organization. Management Communication Quarterly: McQ.

Vergara SC (2006). Gestão de pessoas. 5. ed. São Paulo, SP: Atlas.

Weber M (1999). Economia e Sociedade: fundamentos da sociologia compreensiva. Brasília: UnB. P.464.

Weber M (1976). Os Fundamentos da Organização Burocrática: uma construção do tipo ideal. In CAMPOS, E. Sociologia da Burocracia. Rio de Janeiro: Zahar. P.153.

Weick KE (1995). Sensemaking in organization. London: Sage. 
Yin R (2005). Estudo de caso: planejamento e métodos. Porto Alegre: Bookman.
Ismail W, Abdmajid R (2007). Framework of the culture of innovation: a revisit. Journal Kemanusiaan. 9:38-49. 